\title{
O Estado e o Orçamento
}

A evolução histórica do Estado é paralela à da racionalização do orçamento público, porquanto é difícil imaginar um acontecimento histórico sem ter, como uma das suas causas preponderantes, o fator econômico-financeiro.

A lei de meios é hoje a sintese do programa de trabalho do Estado. Adams Smith considerava o orçamento público como a constituição dinâmica do pais.

A origem histórica das constituições politicas do Estado móderno é, incontestàvelmente, a Carta Magna inglêsa, de 1215, que deu origem ao parlamentarismo na sua acepção mais democrática, quando transformou o Conselho de Nobres daquele país, em órgão de fiscalização e contrôle das despesas do rei, as quais até então eram de livre deliberação do monarca.

As revoluções norte-americana, de independência, e a francêsa, de 1789 , tiveram, em verdade, a sua causa imediata nos excessos de impostos, que sobrecarregaram os dois paises e a malversação dos dinheiros públicos, que caracterizavam a França.

A criação de conselhos, comissões e tribunais de contas, em todos os Estados modernos - depois de adotadas novas constituiçóes politicas, que asseguravam aos povos maiores liberdades e direitos concedeu, também, meios de fiscalizarem, indiretamente, as despesas do Estado, através de prestaçóes de contas dos gastos feitos, a um órgão público, colocado fora do poder executivo, que, na verdade, detém 'o contrôle econômico-financeiro do Estado.

Temos outro exemplo eloqüente na nossa história, quando lembramos que os inconfidentes mineiros de 1791 estabeleceram. como pretexto, a cobrança de impostos atrasados, a fim de levantar - povo contra a metrópole.

O movimento republicano de 1889, que teve um feliz desfecho, baseou-se, em grande parte, na moralização dos gastos públicos, pela prestação de contas das despesas, pelo govêrno, a um tribunal especializado, denominado de Tribunal de Contas, cuja criação 
foi preconizada pelos positivistas, encabeçados por BenJamin Constant. Esste, conjuntamente com RuI BARBOSA, consagrou a instituição dêsse tribunal, na primeira Constituiçâo republicana de 1891.

O balanço orçamentário é um dos indices mais precisos para determinação de acêrto ou de êrro da politica do Govêrno, através do "superavit" ou do "deficit", revelado no exercicio financeiro.

No Brasil, a receita públicá federal representa um quinto da renda nacional; dai a importância de que se reveste, na vida econômico-financeira do pais.

Não há dúvida de que governar é, além de uma função pública, uma gestão de dinheiros públicos na sua concepção mais ampla, pois esta constitui uma das funções mais importantes do Poder Executivo, exercido através da Administração Pública.

A idoneidade do estadista, na gerência do numerário do Estado, é um dos predicados básicos exigidos pela Constituição, pois a sua transgressão representa um dos motivos mais fortes da declaração de Impeachement contra a autoridade responsável, quando se trata dos mais altos magistrados do pais. Há, além das penas especificas previstas no Código Penal, as de outras leis de responsabilidade e as do Estatuto dos Funcionários Públicos Civis da União (Lei n. ${ }^{\circ} 1.711$, de 1952), que abrange a todos os agentes do govêrno e servidores, de maneira geral.

Uma das funções essenciais do Congresso Nacional é a da votação do orçamento público anual e a de contrôle das despesas do Poder Executivo, através de comissões especializadas ou de qualquer membro, isoladamente, e, principalmente, através do seu órgão técnico auxiliar, que é o Tribunal de Contas da União.

O D.A.S.P. representa uma das etapas de racionalização da administração orçamentária do govêrno federal, pois com sua criação, pela Constituição de 1937, ficou definitivamente resolvido o problema de elaboração do projeto da lei de meios, por órgãos técnico do Executivo, quanto anteriormente, essa função era exercida por comissão eventualmente criada, todos os anos, e que funcionava junto ao Ministério da Fazenda. 